\title{
PREDICTION OF AGGREGATE IMPACT VALUES AND AGGREGATE CRUSHING VALUES USING LIGHT COMPACTION TEST
}

\author{
Jayanta Kumar DAS ${ }^{\text {a }}$, Saikat DEB ${ }^{\text {a, }}$, Biswadeep BHARALI ${ }^{\mathrm{a}}$ \\ a Assam down town University, Guwahati, Assam-781026, India, E-mails: kumardasjayanata@ gmail.com, \\ *saikatdeb25@gmail.com, biswadeepbharali1989@gmail.com
}

Received: 27.08.021 / Accepted: 15.09.2021 / Revised: 01.11.2021 / Available online: 15.12.2021

DOI: $10.2478 /$ jaes-2021-0012

KEY WORDS: Aggregate Impact Value, Aggregate Crushing Value, Light Compaction Value, Road Aggregates, Unbound Granular Material.

\begin{abstract}
:
Crushing test and Impact test are very important to estimate strength and toughness characteristics of the road aggregate. Extensive experimental procedures and different sets of equipment are required for these types of aggregate testing. Therefore, the objective of the study is to investigate whether the light compaction test can be a suitable alternative for both these tests. For this experimental procedure, 60 aggregate samples were collected from different rock quarries spread along North-eastern states of India. The specifications of the aggregate samples are kept similar for all of these three test procedures. The result indicates a strong correlation of Light compaction values (LCV) with Aggregate crushing values (ACV) and Aggregate Impact Values (AIV). The $\mathrm{R}^{2}$ values for the relationship was found to be more than 0.9 for both these relationships. It indicates that the LCV can be used to closely predict the ACV and AIV. The root mean square error (RMSE) values estimated based on the actual and predicted values were also found to be low which further concrete the claim that light compaction test can be a suitable alternative for crushing test and impact test of the aggregates.
\end{abstract}

\section{INTRODUCTION}

Aggregates of various sizes are utilized in various applications. For example, aggregates should not be larger than three-quarters of the clear gap between reinforcing bars, however, $40 \mathrm{~mm}$ aggregates should be utilized for structures such as piers, abutments, and retaining walls. Aggregates are also employed as road stones in addition to concrete work. They usually comprise between $75 \%$ and $85 \%$ by volume of Portland and asphalt cement concrete mixes. Hence, it is not surprising that the quality of aggregates is of considerable importance in determining their suitability for any specific engineering application. The effectiveness of aggregates for use is evaluated for a particular construction type by assessing the material in terms of its engineering properties. Hartley (Hartley, 1974) and Lees and Kennedy (Lees and Kennedy, 1975) identified the desired characteristics of road stone aggregate and the effect of geological influences. Simultaneously, ASTM (ASTM, 1978) examined the importance of the tests, properties of concrete, and its components. Relatively sophisticated testing techniques are required to measure the quality of the aggregates. Some of the well-known methods of measuring the strength of an aggregate includes those designed to calculate the abrasion, impact and crushing values of aggregates (BSI British Standards Institution BS 812-110, 1990).

Hardness (or abrasion tolerance) is an essential property of the aggregates.
Different methods were designed to assess the abrasion tolerance of aggregates, with Los Angeles abrasion tests and Deval abrasion tests are the most common (ASTM Designation C-131, 1989). Such experiments are structured to calculate the abrasion properties in a particular way. Mohajerani et. al (Abbas et al., 2017) found that the laboratory-modified compaction method closely simulates the abrasion resistance of the unbound granular materials. In 1980, in Saudi Arabia, Kazi and AL-Mansour (Kazi and Al-Monsour, 1980) found a strong correlation between the uniaxial compressive strength (UCS) and the LA abrasion test. More recently, Kahraman and Toraman (Kahraman and Toraman, 2008) examined the use of the aggregate crushing index to classify the LA abrasion by using a jaw crusher. A similar study was conducted by Ozcelik (Ozcelik, 2011). Kazi and Eyad (Kazi and Mohammad Eyad, 1982) provided correlations between the physical and mechanical properties of 32 different rock types. These features include unit weight, porosity, shore's hardness, uniaxial compressive strength, tensile strength, and points load strength. Mohajerani et al. (Abbas et al., 2017) found that the laboratory-modified compaction method can be an alternative for the Los Angles abrasion test.

Apart from the abrasion test, the crushing value test and impact test are also essential to estimate different aggregate properties.

\footnotetext{
* Corresponding author. Saikat Deb, Civil Engineering Programme, Assam down town University, Email: saikatdeb25@gmail.com
} 
The crushing value test gives a reasonable estimation of the aggregate resistance to crushing under the gradually applied compressive load, while the impact value test gives a comparative measurement of the aggregate resistance to a sudden impact. These types of aggregate testing require sophisticated types of machinery and time-intensive experimental procedures. And more importantly, there are different properties of aggregate which do require different sets of equipment. Therefore, time and resources will be saved if accurate forecasts of the performance of aggregates of one particular test can be generated from the findings of another test. Therefore, the objective of the study is to investigate the possibilities to predict the aggregate impact value and crushing value using the light compaction method. The interaction of the rammer with the aggregates is fairly similar in both the light compaction test and impact test since compaction energy is induced into the tested sample using a repetitive loading technique in both scenarios. Unlike light compaction and impact test, aggregate samples are pressed under statically applied loads in the crushing value test. Moreover, crushing and light compaction tests have the same effect by repeated grinding of aggregates with the steel mechanism and of aggregates crushing against each other. Therefore, this study was suggested in considering the similarities of material handling by the crushing test, impact test, and light compaction test.

\subsection{Aggregate crushing value test (ACV)}

Satisfactory resistance to crushing under the roller during building, and adequate resistance to surface abrasion under traffic, are the main mechanical properties needed for road stone under modern conditions (MARKWICK and SHERGOLD, 1945). The 'Aggregate crushing value provides a relative measure of the resistance of aggregates to crush under a gradually applied compressive load. The Aggregate crushing Test was originally developed at the Road Research Laboratory of Great Britain.

The aggregate crushing value test is normally carried out on aggregates between $10 \mathrm{~mm}$ and $12.5 \mathrm{~mm}$ in scale. In this test, a specified quantity of oven-dried aggregates (about $500 \mathrm{~g}$ ) that have been sieved between $10 \mathrm{~mm}$ and $12.5 \mathrm{~mm}$ Indian Standard sieves, is placed in a $7.5 \mathrm{~cm}$ diameter cylindrical steel mould in three layers of approximately equal thickness. Each layer should be tempted 25 times manually with the round end of the tamping road to level the surface. A firmly fitted plunger is placed over it and is subjected to a load increasing uniformly to 40 tons in 10 minutes ((BIS), 1970; Bureau of Indian Standards (BIS), 2002).

The aggregate crushing value, which is an inverse measure of mechanical strength of aggregate, is determined by the percentage of fines passing through $2.36 \mathrm{~mm}$ IS sieve after test and it is largely influenced by factors such as the size of the test sample, total applied load and rate of application, drying condition, and method of compacting the aggregates in the cylinder before the test.

\subsection{Aggregate impact value test (AIV)}

The aggregates are exposed to impact due to the passage of vehicles on the road, resulting in their breaking down into smaller parts. Therefore, the aggregates should have enough toughness to resist their disintegration due to impact. The aggregate impact value is a measure of sudden impact or shock resistance, which may vary from its gradually applied compressive load resistance.

In the Aggregate impact value test, a small portion of coarse aggregates having a size range between 10 to $12.5 \mathrm{~mm}$, is confined in a $75 \mathrm{~mm}$ diameter cylindrical metal measure and subjected to 15 blows by a standard hammer weighing 13.5 to $14.0 \mathrm{~kg}$ falling freely from a height of $380 \pm 5.0 \mathrm{~mm}$ attached to the Impact testing machine (Bureau of Indian Standards (BIS), 2002).

The materials finer than $2.36 \mathrm{~mm}$ resulting from the heavy striking of the hammer will indicate the toughness of the sample of aggregates. According to IS 383-1970 ((BIS), 1970), the impact value of aggregates is defined as the ratio of the weight of fines produced to the weight of the total sample taken and is expressed in a percentage. The following table shows the aggregate classification proposed by the Indian Road Congress concerning the aggregate impact value for various types of road construction.

\begin{tabular}{|c|c|}
\hline $\begin{array}{c}\text { Aggregate Impact } \\
\text { Value }\end{array}$ & Classification \\
\hline$<10 \%$ & Exceptionally Strong \\
\hline $10-20 \%$ & Strong \\
\hline $20-30 \%$ & Satisfactory for road surfacing \\
\hline$<35 \%$ & Weak for road surfacing \\
\hline
\end{tabular}

Table 1. Aggregate classification based on AIV (Of et al., 2005)

\section{EXPERIMENT WORKS}

\subsection{Materials}

In consideration of the fact that not all roads are made from the same materials, the procurement of materials was carried out on the number of stone quarry widely spaced over the north-eastern states of India to provide an experimental study of a wide variety of granular materials of different sizes, classes, and rock forms. Total 20 numbers of prominent quarries in Northeast region (shown in Figure 1) of India have been selected for the present study and three aggregate samples have been collected from each quarry. The locations of each selected quarry are shown in Table 2.

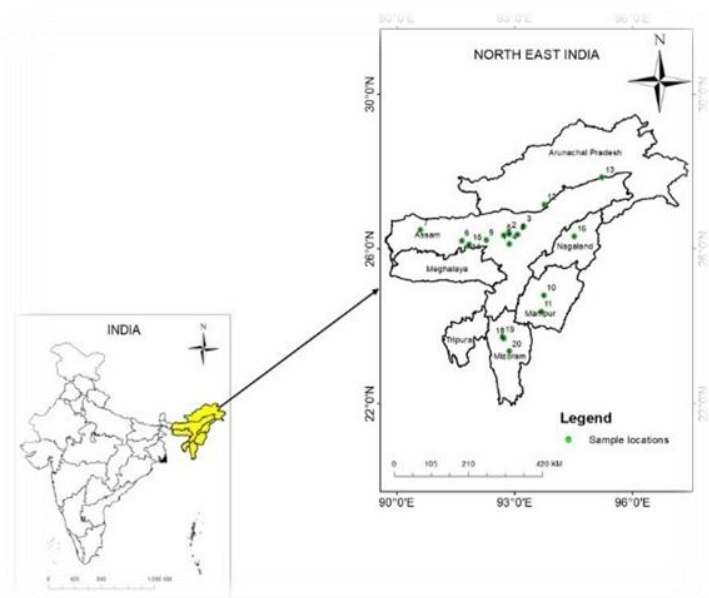

Figure 1. Map showing source of test aggregate samples 


\subsection{Aggregate crushing value test (ACV) \& Aggregate impact value test (AIV)}

Each aggregate sample was tested in the laboratory for crushing value and impact value following the specification recommended by the BIS code (Bureau of Indian Standards (BIS), 2002).

\subsection{Light compaction test}

Compaction is generally defined as a field or laboratory process to improve geotechnical properties of soil, which can be achieved by altering the orientation of its structure and by densifying the soil mass. Ralph Roscoe Proctor developed the soil compaction technique originally from 1930-33 to determine the overall dry weight of the soil unit (Proctor, 1948; Budhu, 2010). During the 1930s, mechanical strength experiments were conducted using techniques similar to the subsequent ASTM D1558-10 (Proctor, 1945). Since its inception, in the study of the unbound granular materials used in road construction, the Proctor's dynamic compaction technique has been the most frequently used compaction process (Cerni and Camilli, 2011).

\begin{tabular}{|c|c|c|c|c|c|}
\hline $\begin{array}{c}\text { Sample } \\
\text { no. }\end{array}$ & Locations & $\begin{array}{l}\text { District, } \\
\text { State }\end{array}$ & Latitude & Longitude & Nominal Size \\
\hline S1 & Kathal guri quarry & Naogaon, Assam & $2622^{\prime} 49^{\prime \prime} \mathrm{N}$ & $9251^{\prime} 43^{\prime \prime} \mathrm{E}$ & $\begin{array}{c}20 \mathrm{~mm} \\
\text { Crushed Stone }\end{array}$ \\
\hline S2 & Samaguri quarry & Naogaon, Assam & $2625^{\prime} 0^{\prime \prime} \mathrm{N}$ & 92 51' 0" E & $\begin{array}{c}20 \mathrm{~mm} \\
\text { Crushed Stone }\end{array}$ \\
\hline S3 & Bagori quarry & Naogaon, Assam & $2635^{\prime} 01^{\prime \prime} \mathrm{N}$ & $9313^{\prime} 58^{\prime \prime} \mathrm{E}$ & $\begin{array}{c}14 \text { mm River } \\
\text { Stone }\end{array}$ \\
\hline S4 & Doboka quarry & Naogaon, Assam & $2607^{\prime} 02^{\prime \prime} \mathrm{N}$ & $9251^{\prime} 48 " \mathrm{E}$ & $\begin{array}{c}20 \mathrm{~mm} \\
\text { Crushed Stone }\end{array}$ \\
\hline S5 & Dimoru guri quarry & Naogaon, Assam & $2620^{\prime} 43^{\prime \prime} \mathrm{N}$ & $9243^{\prime} 0 " \mathrm{E}$ & $\begin{array}{c}20 \mathrm{~mm} \\
\text { Crushed Stone }\end{array}$ \\
\hline S6 & Agyathuiri Stone quarry & $\begin{array}{c}\text { Kamrup rural, } \\
\text { Assam }\end{array}$ & $2612^{\prime} 18^{\prime \prime} \mathrm{N}$ & $9139^{\prime} 20^{\prime \prime} \mathrm{E}$ & $\begin{array}{c}20 \mathrm{~mm} \\
\text { Crushed Stone }\end{array}$ \\
\hline S7 & $\begin{array}{l}\text { Chaprakata Hill stone } \\
\text { quarry }\end{array}$ & Bongaigaon, Assam & $2629^{\prime} 06^{\prime \prime} \mathrm{N}$ & 9036 ' 02" E & $\begin{array}{c}20 \mathrm{~mm} \\
\text { Crushed Stone }\end{array}$ \\
\hline S8 & Parkup Pahar & $\begin{array}{c}\text { Karbi-anglong, } \\
\text { Assam }\end{array}$ & $2622^{\prime} 02^{\prime \prime} \mathrm{N}$ & $9304^{\prime} 10^{\prime \prime} \mathrm{E}$ & $\begin{array}{c}14 \text { mm River } \\
\text { stone }\end{array}$ \\
\hline S9 & $\begin{array}{l}\text { Boghora stone mahal } \\
\text { no. } 10\end{array}$ & Morigaon, Assam & $2613^{\prime} 39^{\prime \prime} \mathrm{N}$ & $9216^{\prime} 33^{\prime \prime} \mathrm{E}$ & $\begin{array}{c}14 \text { mm River } \\
\text { stone }\end{array}$ \\
\hline $\mathrm{S} 10$ & Paneh stone quarry & Senapati, Manipur & $2447^{\prime} 50^{\prime \prime} \mathrm{N}$ & $9344^{\prime} 26^{\prime \prime} \mathrm{E}$ & $\begin{array}{c}14 \text { mm River } \\
\text { stone }\end{array}$ \\
\hline $\mathrm{S} 11$ & Teiseng quarry & $\begin{array}{c}\text { Churachandpur, } \\
\text { Manipur }\end{array}$ & $2422^{\prime} 41^{\prime \prime} \mathrm{N}$ & $9324^{\prime} 10.8^{\prime \prime} \mathrm{E}$ & $\begin{array}{c}20 \mathrm{~mm} \\
\text { Crushed Stone }\end{array}$ \\
\hline $\mathrm{S} 12$ & Doimukh & $\begin{array}{c}\text { Papumpare, } \\
\text { Arunachal Pradesh }\end{array}$ & 27 8' 39.12" N & $9345^{\prime} 14.4^{\prime \prime} \mathrm{E}$ & $\begin{array}{c}20 \mathrm{~mm} \\
\text { Crushed Stone }\end{array}$ \\
\hline $\mathrm{S} 13$ & Ruksin & $\begin{array}{c}\text { East Siang, } \\
\text { Arunachal Pradesh }\end{array}$ & $2715^{\prime} 43.08^{\prime \prime} \mathrm{N}$ & $\begin{array}{c}9513^{\prime} 31.44^{\prime \prime} \\
\mathrm{E}\end{array}$ & $\begin{array}{c}20 \mathrm{~mm} \\
\text { Crushed Stone }\end{array}$ \\
\hline $\mathrm{S} 14$ & Umnave stone quarry & Ri-bhoi, Meghalaya & $264^{\prime} 28.66 " \mathrm{~N}$ & $\begin{array}{c}9149^{\prime} 25.74 " \\
\mathrm{E}\end{array}$ & $\begin{array}{c}20 \mathrm{~mm} \\
\text { Crushed Stone }\end{array}$ \\
\hline S15 & Killing Road & Ri-bhoi, Meghalaya & $2606^{\prime} 15^{\prime \prime} \mathrm{N}$ & $9150^{\prime} 46^{\prime} \mathrm{E}$ & $\begin{array}{c}20 \mathrm{~mm} \\
\text { Crushed Stone }\end{array}$ \\
\hline S16 & $\begin{array}{l}\text { Mokokchung stone } \\
\text { quarry }\end{array}$ & $\begin{array}{l}\text { Mokokchung, } \\
\text { Nagaland }\end{array}$ & $2619^{\prime} 19.2^{\prime \prime} \mathrm{N}$ & $9430^{\prime} 48.6^{\prime} \mathrm{E}$ & $\begin{array}{c}20 \mathrm{~mm} \\
\text { Crushed Stone }\end{array}$ \\
\hline S17 & Sri Naga stone quarry & $\begin{array}{c}\text { Kancheeuram, } \\
\text { Nagaland }\end{array}$ & $1249^{\prime} 6.6^{\prime \prime} \mathrm{N}$ & $\begin{array}{c}7941^{\prime} 40.92^{\prime} \\
\mathrm{E}\end{array}$ & $\begin{array}{c}20 \mathrm{~mm} \\
\text { Crushed Stone }\end{array}$ \\
\hline S18 & Hlimen Quarry & Aizwal, Mizoram & $2340^{\prime} 52^{\prime \prime} \mathrm{N}$ & $9243^{\prime} 3^{\prime \prime} \mathrm{E}$ & $\begin{array}{c}20 \mathrm{~mm} \\
\text { Crushed Stone }\end{array}$ \\
\hline S19 & Lawipu stone quarry & Aizwal, Mizoram & $2343^{\prime} 34.6 " \mathrm{~N}$ & $9241^{\prime} 3.84 " \mathrm{E}$ & $\begin{array}{c}20 \mathrm{~mm} \\
\text { Crushed Stone }\end{array}$ \\
\hline S20 & Marami Quarry & Aizwal, Mizoram & $2321^{\prime} 1.8 " \mathrm{~N}$ & $\begin{array}{c}9251^{\prime} 45.36 " \\
\mathrm{E}\end{array}$ & $\begin{array}{c}20 \mathrm{~mm} \\
\text { Crushed Stone }\end{array}$ \\
\hline
\end{tabular}

Table 2. Experimental material samples and their locations 
In general, various standards can be used to perform a compaction test: IS:2720-7 (Bureau of Indian Standards, 1980), IS: 2720-8, 1983 (Bureau of Indian Standards, 1983), ASTM D698 (American Society for Testing and Materials ASTM D6928, 2010), and BSI 1377-4 (BSI British Standards Institution BS 1377-4, no date).

There are two types of compaction techniques are available in India: the light compaction method (Bureau of Indian Standards, 1980) and the heavy compaction method (Bureau of Indian Standards, 1983). The Indian standard compaction techniques incorporate the use of two different steel rammers, $2.6 \mathrm{~kg}$ or $4.9 \mathrm{~kg}$ to apply a definite number of repeated loads on the well-prepared materials filled in standard compaction mould (10 cm diameter and $13 \mathrm{~cm}$ height) depending on the standards followed (Bureau of Indian Standards, 1980, 1983). The experimental setup is shown in Figure 2.

The manually operated light compaction technique was used in the present study as it is comparatively less tedious and required less time. In this study, the $2.6 \mathrm{~kg}$ compaction rammer was used in accordance with IS:2720-7 (Bureau of Indian Standards, 1980). Light compaction test setup is shown in Figure 2. Moreover, as per the standard, the number of blows of the rammer is fixed as 25 and the sample was compacted into three layers.

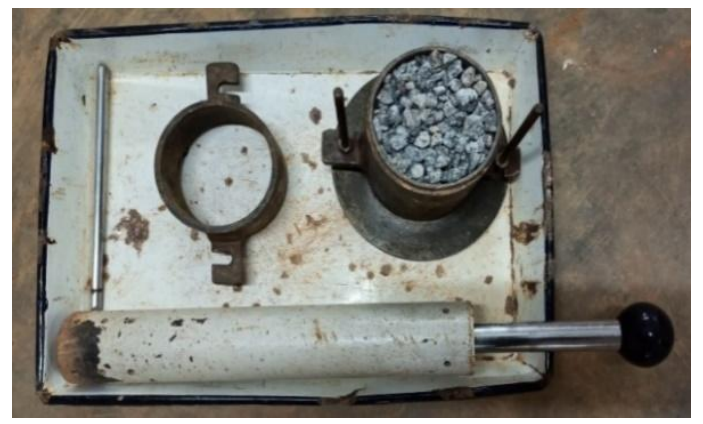

Figure 2. Light compaction test setup

The material used in the compaction test, sieving procedure (passing through IS $12.5 \mathrm{~mm}$ sieve and retained on IS $10 \mathrm{~mm}$ sieve), oven drying of the sample (temperature ranges from 100110 degrees Celsius) are kept similar to crushing test and impact test. For the compaction test, the materials are placed in the compaction mould in three layers and each layer is rammed with 25 number of $2.6 \mathrm{~kg}$ rammer blows. The remaining steps were kept similar to of impact test and crushing test i.e., the materials are sieved through IS $2.36 \mathrm{~mm}$ sieve, and the weight of crushed material passing through IS $2.36 \mathrm{~mm}$ sieve is recorded.

The compaction test value is estimated as a percentage of the weight of passing materials through IS $2.36 \mathrm{~mm}$ sieve to the total weight of the material as similar to the impact and crushing test. The initial weight of the materials taken for the tests are approximately $480 \mathrm{gm}$ for crushing test, $350 \mathrm{gm}$ for impact test and $2000 \mathrm{gm}$ for compaction test.

\section{RESULT AND DISCUSSION}

The summary of the results obtained from the Compaction test, Impact test, and Crushing value test are shown in Table 3. It can be observed from Table 3 that compaction values for samples S3, S8, S9, and S10 are highest compared to other samples. It could be understood that, as they are sourced from river stones, therefore, their compaction values are found to be higher. Moreover, their nominal sizes are also found to be lower compared to the other samples. For the impact test, the highest results are found from similar test samples. But for the crushing test, slightly different results have been observed for sample number S8. This can be attributed to their different sources which may lead to different properties of the aggregates. This indicates that these test results not only depend on aggregate nominal size but their basic properties too. Moreover, it can be noted that the crushing values are found to be nearer to the compaction values.

The relationship between compaction, crushing, and impact test is established using regression analysis. The relationship is established based on the values of the first 14 samples (S1 to S14). The rest of the sample results are used to validate our findings.

\begin{tabular}{|c|c|c|c|c|}
\hline $\begin{array}{c}\text { Sample } \\
\text { no. }\end{array}$ & Nominal Size & $\begin{array}{l}\text { Compaction } \\
\text { Test (in \%) }\end{array}$ & $\begin{array}{c}\text { Impact } \\
\text { Test (in } \\
\% \text { ) }\end{array}$ & $\begin{array}{c}\text { Crush- } \\
\text { ing } \\
\text { Value } \\
\text { Test (in } \\
\% \text { ) }\end{array}$ \\
\hline S1 & $\begin{array}{c}20 \mathrm{~mm} \\
\text { Crushed Stone }\end{array}$ & 26.217 & 36.212 & 24.235 \\
\hline S2 & $\begin{array}{c}20 \mathrm{~mm} \\
\text { Crushed Stone }\end{array}$ & 26.119 & 35.404 & 24.567 \\
\hline S3 & $\begin{array}{l}14 \text { mm River } \\
\text { Stone }\end{array}$ & 37.335 & 47.701 & 34.4 \\
\hline S4 & $\begin{array}{c}20 \mathrm{~mm} \\
\text { Crushed Stone }\end{array}$ & 15.448 & 26.284 & 13.32 \\
\hline S5 & $\begin{array}{c}20 \mathrm{~mm} \\
\text { Crushed Stone }\end{array}$ & 11.54 & 22.233 & 10.42 \\
\hline S6 & $\begin{array}{c}20 \mathrm{~mm} \\
\text { Crushed Stone }\end{array}$ & 9.03 & 18.543 & 9.1 \\
\hline S7 & $\begin{array}{c}20 \mathrm{~mm} \\
\text { Crushed Stone }\end{array}$ & 24.57 & 35.63 & 22.72 \\
\hline S8 & $\begin{array}{l}14 \mathrm{~mm} \text { River } \\
\text { stone }\end{array}$ & 20.52 & 40 & 19.65 \\
\hline S9 & $\begin{array}{l}14 \mathrm{~mm} \text { River } \\
\text { stone }\end{array}$ & 31.54 & 43.2 & 29.93 \\
\hline S10 & $\begin{array}{c}14 \mathrm{~mm} \text { River } \\
\text { stone }\end{array}$ & 28.52 & 39.54 & 28.5 \\
\hline S11 & $\begin{array}{c}20 \mathrm{~mm} \\
\text { Crushed Stone }\end{array}$ & 12.87 & 23.64 & 11.7 \\
\hline S12 & $\begin{array}{c}20 \mathrm{~mm} \\
\text { Crushed Stone }\end{array}$ & 22.34 & 32.03 & 22.7 \\
\hline S13 & $\begin{array}{c}20 \mathrm{~mm} \\
\text { Crushed Stone }\end{array}$ & 27.02 & 36.52 & 26.5 \\
\hline S14 & $\begin{array}{c}20 \mathrm{~mm} \\
\text { Crushed Stone }\end{array}$ & 16.8 & 25.32 & 16.5 \\
\hline S15 & $\begin{array}{c}20 \mathrm{~mm} \\
\text { Crushed Stone }\end{array}$ & 6.52 & 15.42 & 7 \\
\hline S16 & $\begin{array}{c}20 \mathrm{~mm} \\
\text { Crushed Stone }\end{array}$ & 21.56 & 30.5 & 19.23 \\
\hline S17 & $\begin{array}{c}20 \mathrm{~mm} \\
\text { Crushed Stone }\end{array}$ & 17.02 & 26.34 & 16.12 \\
\hline S18 & $\begin{array}{c}20 \mathrm{~mm} \\
\text { Crushed Stone }\end{array}$ & 12 & 21.34 & 11.5 \\
\hline
\end{tabular}




\begin{tabular}{|c|c|c|c|c|}
\hline S19 & $\begin{array}{c}20 \mathrm{~mm} \\
\text { Crushed } \\
\text { Stone }\end{array}$ & 12.45 & 21.32 & 10.58 \\
\hline S20 & $\begin{array}{c}20 \mathrm{~mm} \\
\text { Crushed } \\
\text { Stone }\end{array}$ & 17.4 & 26.57 & 15.78 \\
\hline
\end{tabular}

Table 3. Result summary for compaction test, impact test, and crushing value test

Table 4 shows the model fitness values for the regression analysis estimated based on the relationship between the light compaction test and the crushing test.

Here, the values of the compaction test are used as an independent variable. This table provides $R, R^{2}$, adjusted $R^{2}$, Standard error of the estimates. ' $R$ ' represents multiple correlation coefficients which could be considered as one of the qualitative measures of the prediction of the dependent variable (Field, 2003; Deb and Ahmed, 2018).

A value of 0.994 indicates a good level of prediction of aggregate crushing value. The $\mathrm{R}^{2}$ value or coefficient of determination represents the proportion of variance that can be explained by the independent variable (Field, 2003; Deb and Ahmed, 2019). From the $\mathrm{R}^{2}$ value, it can be said that the independent variable light compaction explains $98.8 \%$ of the variability of the dependent variable. $\mathrm{R}^{2}$ at first glance tends to be statistically easy to understand which shows how well a regression model suits a data set. However, to get a comprehensive idea about the model, one must consider adjusted $\mathrm{R}^{2}$ and standard error of the estimates in addition to $\mathrm{R}^{2}$.

Adjusted $\mathrm{R}^{2}$ is very important for data interpretation. A value of 0.987 in Table 4 indicates true $98.7 \%$ of the variation in the outcome variable is explained by the predictors which are to keep in the model. The wide difference between $R^{2}$ values and Adjusted $\mathrm{R}^{2}$ indicates a poorly fitted model. From Table 4 , it could be seen that for our case both these $R^{2}$ values are very close which indicates a good fit of our data (Field, 2003).

The standard error is a measure of model accuracy. It represents the standard deviation of the residuals. Standard error will decrease with the increase of $\mathrm{R}^{2}$ values (Field, 2003). From the standard error values, it can be said that the estimation of crushing test value with the help of the light compaction test will be wrong by 0.90 which can be ignored.

\begin{tabular}{|c|c|c|c|c|}
\hline Model & R & $\begin{array}{c}\text { R } \\
\text { Square }\end{array}$ & $\begin{array}{c}\text { Adjusted R } \\
\text { Square }\end{array}$ & $\begin{array}{c}\text { Std. Error of } \\
\text { the Estimate }\end{array}$ \\
\hline 1 & 0.994 & 0.988 & 0.987 & 0.907 \\
\hline
\end{tabular}

Table 4. Model fitness values for the regression analysis based on the relationship between light compaction test and crushing test

Table 5 shows the estimated model coefficients for regression analysis based on the relationship between light compaction test and crushing test. The general equation is given below:

Crushing value $=0.951 \times$ light compaction value -0.042

\begin{tabular}{|c|c|c|c|}
\hline \multirow{2}{*}{ Model } & \multicolumn{2}{|c|}{ Unstandardized Coefficient } & \multirow{2}{*}{ Sig. } \\
\cline { 2 - 3 } & B & Std. Error & 0.954 \\
\hline 1 (Constant) & -0.042 & 0.724 & 0.951 \\
\cline { 2 - 3 } Compaction & 0.951 & 0.031 & 0.000 \\
\hline
\end{tabular}

Table 5. Coefficients for regression analysis based on the relationship between light compaction test and crushing test

The statistical significance of the independent variable is also shown in Table 5. The significant values (sig.) indicate whether an independent variable is needed to predict the dependent variable. The constant value -0.042 is the predicted value for the dependent variable if the value of the independent variable is kept at 0 .

The significant value for the constant term is found to be higher than 0.05. It indicates that the constant term is insignificant. But as per Martin (Martin, 2018), the constant term does not have any meaningful interpretation. Therefore, the insignificant value of the constant term will not affect the fit of the model (Field, 2003). However, as the constant term places the regression line in the right place, therefore, the constant term should always be mentioned in the regression model.

The significant value (sig.) for the independent variable is found to be 0.00 (which is lesser than 0.05) indicating that the light compaction values are very much significant in predicting the crushing test values. The standard error for the independent variable is also found to be lower which indicate a good fitted model.

Unstandardized regression coefficients indicate the changes in the dependent variable with one unit increase in the independent variable. Referring to Table 5 the unstandardized coefficient for the light compaction test is found to be 0.951 . It indicates that every unit increase in light compaction values will increase the crushing value with an amount of 0.951 .

Table 6 shows the model summary for the regression analysis estimated based on the relationship between the light compaction test and the impact test.

The values of $R, R^{2}$ and adjusted $R^{2}$ values are found to be satisfactory for this model too. Table 7 indicates a summary of the regression model. In this model light, compaction value is used as an independent variable which is found to be significant from Table 7. The relationship between light compaction and impact value can be expressed by the following equation:

Impact value $=1.004 \times$ light compaction value +10.788

\begin{tabular}{|c|c|c|c|}
\hline Model & R & $\begin{array}{c}\text { Adjusted R } \\
\text { Square }\end{array}$ & $\begin{array}{c}\text { Std. Error of } \\
\text { the Estimate }\end{array}$ \\
\hline 2 & 0.953 & 0.908 & 2.7233949 \\
\hline
\end{tabular}

Table 6. Model fitness values for the regression analysis based on the relationship between light compaction test and impact test 


\begin{tabular}{|c|c|c|c|}
\hline \multirow{2}{*}{ Model } & \multicolumn{2}{|c|}{ Unstandardized Coefficient } & \multirow{2}{*}{ Sig. } \\
\cline { 2 - 3 } & B & Std. Error & \\
\hline 2 (Constant) & 10.788 & 2.171 & 0.000 \\
\cline { 2 - 3 } Compaction & 1.004 & 0.092 & 0.000 \\
\hline
\end{tabular}

Table 7. coefficients for regression analysis based on the relationship between light compaction test and crushing test

\section{MODEL VALIDATION}

As discussed earlier, the model is validated based on the last six sample data and root mean square error (RMSE) values are estimated based on the actual and predicted values. In Figure 3 the actual and predicted graph for crushing values based on Eq. 1 is shown. The range of the crushing test value is found to vary from $7 \%$ to $34.4 \%$. The RMSE value for the model is found to be 0.84 indicating a well-fitted model.

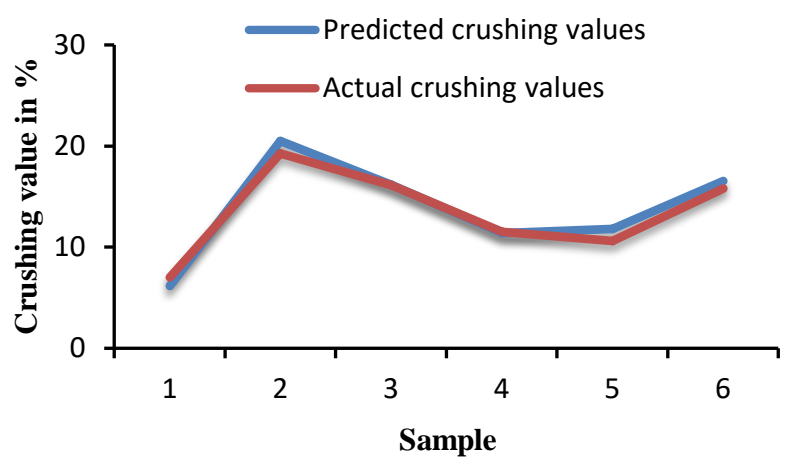

Figure 3. Actual vs Predicted Crushing values

Similarly, in Figure 4 the graph for actual and predicted impact values based on Eq. 2 is shown. The range of the crushing values is found to be $15.42 \%$ to $47.7 \%$. The RMSE value is found to be 1.76 indicating a well-fitted model.

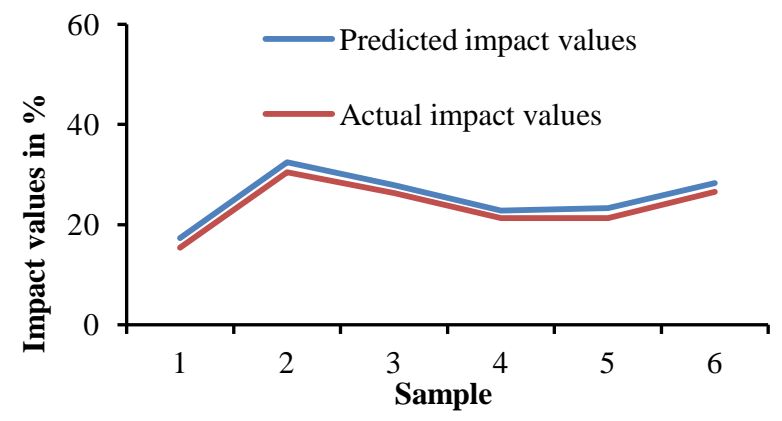

Figure 4. Actual vs Predicted Impact Values

\section{CONCLUSION}

The purpose of this study was to examine the possibility of using the light compaction method to assess the AIV and ACV of the unbound granular materials used in road construction as an alternative to the Aggregate impact value method and Aggregate crushing value method.

As aggregate crushing and impact tests require a different set of equipment, therefore, the motive behind the study is to accurately predict their test results using a simplified test procedure (light compaction test). There are similarities in the material used for the crushing test and impact test. In both the light-compaction test and the impact test, the interaction of the rammer with the aggregates is quite similar.

Crushing and light compaction tests have the same effect by repeated grinding of aggregates by the steel mechanism and of aggregates crushing against each other.

For this study, a total number of 20 rock queries spread through the northeaster region of India were selected to collect the aggregate sample. These aggregates were used to perform impact tests, crushing tests, and proposed light compaction tests.

For each test, three specimens from the same batch of aggregate were tested. After estimating the test results, relationships have been established using regression analysis to predict the crushing value and impact value of aggregate using the light compaction test values. Among the 20 samples, 14 sample results were used to establish the relationship, and the remaining 6 sample results are used for model validation.

The result indicates a strong correlation between the crushing test and light compaction test values. The $\mathrm{R}^{2}$ value for this relationship was found to be 0.988 . Similarly, the $R^{2}$ value of the regression analysis established based on the relationship between light compaction test and impact test was found to be 0.908. It indicates that the light compaction test values can be used to accurately predict the crushing values and impact values of aggregate.

The RMSE values estimated based on the actual and predicted values were also found to be low which further concrete the claim that the light compaction test can be a suitable alternative for crushing test and impact test of the aggregates.

It should be noted that the proposed relationship has been established with total compaction energy of $592.5 \mathrm{~kJ} / \mathrm{m} 3$ based on the Indian standard light compaction method (IS:2720-7, 1980).

The proposed correlations and the new approach could be invalidated by any changes in this compaction energy. Based on the results of this research, it is suggested that the light compaction method should be applied instead of using the Impact test method and Crushing test to assess the toughness and compressive strength characteristics of unbound granular materials respectively since the light compaction procedure requires less space and time. 


\subsection{Acknowledgements}

The authors are thankful to Civil Engineering Programme, Assam down Town University for necessary support and laboratory facilities.

\section{References}

(BIS), B. of I. S. (1970) 'IS 383: 1970 Specification for Coarse and Fine Aggregates From Natural Sources for Concrete', Indian Standards, pp. 1-24.

Abbas, M. et al. (2017) 'A new practical method for determining the LA abrasion value for aggregates', Soils and Foundations, 57, pp. 840-848.

American Society for Testing and Materials ASTM D6928 (2010) Standard test Method for Resistance of Coarse Aggregate to Degradation by Abrasion in the Micro-deval Apparatus.

ASTM (1978) Signifacnce of Tests and Properties of Concrete Making Materials, ASTM Designation STP 169 B.

ASTM Designation C-131 (1989) Resistance to abrasion of small-size coarse aggregate by use of the LOS Angeles machine.

BSI British Standards Institution BS 1377-4 (no date) Methods of Test for Soils for Civil Engineering Purposes.

BSI British Standards Institution BS 812-110 (1990) Testing aggregates - Part 110: Methods for determination of aggregate crushing value (ACV).

Budhu, M. (2010) Soil Mechanics and Foundations. 3rd edn. United States of America: John Wiley \& Sons Inc.

Bureau of Indian Standards (1980) Indian Standards, Methods of Test for Soils, Part 7: Determination of Water Content-Dry Density Relation using Light Compaction.

Bureau of Indian Standards (1983) 'Determination of water content-dry density relation using heavy compaction', Is : 2720, Part VIII, pp. 3562-3577. doi: /1992.70113551x.

Bureau of Indian Standards (BIS) (2002) 'IS : 2366 (Part IV )-1963-Methods of test for Aggregates for Concrete, part 4 : Mechanical properties', Indian Standards, pp. 1-37.

Cerni, G. and Camilli, S. (2011) 'Comparative analysis of gyratory and proctor compaction processes of unbound granular materials', Road materials and pavement design, 12(2), pp. 397-421.

Deb, S. and Ahmed, M. A. (2019) 'Quality assessment of city bus service based on subjective and objective service quality dimensions: Case study in Guwahati, India', Benchmarking: An International Journal, 26(2), pp. 567-
589. doi: 10.1108/BIJ-11-2017-0309.

Deb, S. and Ahmed, M. A. A. (2018) 'Variability of the Perception About Safety, Comfort , Accessibility and Reliability of City Bus Service Across Different Users ' Groups', International Journal of Civil Engineering and technology, 9(2), pp. 188-204.

Field, A. P. (2003) 'Exploratory factor analysis', Discovering Statistics Using SPSS, (1979), pp. 1-36. doi: 10.1007/s13398-014-0173-7.2.

Hartley, A. (1974) 'A review of the geological factors influencing the mechanical properties of road surface aggregates', Quarterly Journal of Engineering Geology, 7(1), pp. 69-100.

IS:2720-7 (1980) 'Indian Standards, Methods of Test for Soils, Part 7: Determination of Water Content-Dry Density Relation using Light Compaction', Bureau of Indian Standards, Reaffirmed(2011), pp. 1-9.

Kahraman, S. and Toraman, O. . (2008) 'Predicting Los Angeles abrasion loss of rock aggregates from crushability index', Bulletin of Materials Science, 31(2), pp. 173-177.

Kazi, A. and Al-Monsour, Z. (1980) 'Empirical relationship between Los Angeles abrasion and Schmidt hammer strength tests with application to aggregates around Jeddah', Quarterly Journal of Engineering, 13(1), pp. 45-52.

Kazi, A. and Mohammad Eyad, A.-M. (1982) 'Empirical relationship between Los Angeles abrasion and aggregate impact value tests.', in International Association of Engineering Geology. International congress, pp. 293-299.

Lees, G. and Kennedy, C. (1975) 'Quality, shape and degradation of aggregates', Quarterly Journal of Engineering, 8(3), pp. 193-209.

MARKWICK, A. H. D. and SHERGOLD, F. A. (1945) 'THE AGGREGATE CRUSHING TEST FOR EVALUATING THE MECHANICAL STRENGTH OF COARSE AGGREGATES.', Journal of the Institution of Civil Engineers. doi: 10.1680/ijoti.1945.12252.

Martin, K. G. (2018) Interpreting Regression Coefficients. Available at: https://www.theanalysisfactor.com/interpreting-regressioncoefficients (Accessed: 13 June 2018).

Of, M. et al. (2005) 'Aggregates Impact Value of Soft Aggregates Impact Value of Soft', 1970(Reaffirmed 2003).

Ozcelik, Y. (2011) 'Predicting Los Angeles abrasion of rocks from some physical and mechanical properties', Scientific Research and Essays, 6(7), pp. 1612-1619.

Proctor, R. . (1945) 'Proctor on military airfield', American Society of Civil Engineers (ASCE), 110, pp. 799-809. 
Proctor, R. . (1948) 'Laboratory soil compaction methods, penetration resistance measurements, and the indicated saturated penetration resistance', in In: Proceedings of the Second International Conference on Soil Mechanics and Foundation Engineering, pp. 242-247. 